\title{
Microbial and Parasitic Contamination on Fresh Vegetables Sold in Traditional Markets in Hue City, Vietnam
}

\author{
Ho Le Quynh Chau ${ }^{1, *}$, Ho Trung Thong ${ }^{1}$, Nguyen Van Chao ${ }^{1}$, Pham Hoang Son Hung ${ }^{1}$, Vu Van Hai ${ }^{1}$, Le Van An ${ }^{1}$, \\ Ayako Fujieda ${ }^{2}$, Tanaka Ueru ${ }^{3}$, Miki Akamatsu ${ }^{4}$ \\ ${ }^{1}$ College of Agriculture and Forestry, Hue University, Vietnam \\ ${ }^{2}$ Graduate School of Global Environmental Studies, Kyoto University, Japan \\ ${ }^{3}$ Research Institute for Humanity and Nature, Kyoto, Japan \\ ${ }^{4}$ Graduate School of Agriculture, Kyoto University, Japan \\ *Corresponding author: holequynhchau@huaf.edu.vn
}

Received October 29, 2014; Revised November 12, 2014; Accepted November 20, 2014

\begin{abstract}
This study was conducted to evaluate microbial and parasitic contamination in twelve types of popular vegetables in Hue city. A total of 108 vegetable samples, equal numbers of young mustard greens, celery, amaranth, cilantro, water spinach, rice paddy herb, Vietnamese cilantro, basil, centella, lettuce, watercress, and iceberg lettuce were collected from three traditional markets in Hue city. All of samples were tested for total aerobic bacteria counts and $E$. coli by traditional culture-based methods. The Salmonella and parasites on the vegetables were detected by PCR technique and microscopic methods, respectively. All samples were highly contaminated with aerobic bacteria and E. coli. The aerobic bacteria counts ranged from 6.84 to $8.40 \mathrm{log}$ CFU/g. Escherichia coli levels ranged from $5.47-6.88 \log$ CFU/g. Salmonella was detected in 19/108 of test samples. Water spinach was found to have the highest contamination prevalence with Salmonella (55.56\%). Contamination by multiple parasites was detected in all vegetable samples. The contamination rates of Fasciola, Ascaris, Trichuris and Clonorchis sinensis eggs were 83.33\%, 85.19\%, 64.81\% and 16.67\%, respectively. The oocysts of Cryptosporidium, Isospora and Cyclospora were found on the samples at rates of $47.22 \%, 27.78 \%$ and $27.78 \%$, respectively. These bacteria and parasites may become potential sources of cross contamination and pose a serious risk to human health.
\end{abstract}

Keywords: aerobic bacteria, E. coli, parasite, Salmonella, vegetable

Cite This Article: Ho Le Quynh Chau, Ho Trung Thong, Nguyen Van Chao, Pham Hoang Son Hung, Vu Van Hai, Le Van An, Ayako Fujieda, Tanaka Ueru, and Miki Akamatsu, "Microbial and Parasitic Contamination on Fresh Vegetables Sold in Traditional Markets in Hue City, Vietnam." Journal of Food and Nutrition Research, vol. 2, no. 12 (2014): 959-964. doi: 10.12691/jfnr-2-12-16.

\section{Introduction}

Vegetables are essential ingredients in Vietnamese diet. Many kinds of vegetables are consumed fresh (raw) and provide benefit nutrients as vitamins, fiber and ash for human body. However, these vegetables may be a potential source of infection if they are contaminated. Evaluation of hygienic-sanitary quality of vegetables is not only based on chemical safety (pesticide and hormone residues, heavy metals) but biological safety (bacteria and parasites).

Cases of food poisoning due to vegetable consumption have been reported. Contamination with bacteria (especially E. coli and Salmonella) and parasites on vegetables have been reported in many countries $([11,16,24])$. Salmonella was detected in $5.76 \%$ of the examined vegetables in Mexico [16]. Meanwhile, E. Salmonella and E. coli were found on $7.5 \%$ and $86.1 \%$ of the vegetable samples collected from farms, a wholesale market, supermarkets and small shops in Granada, Spain [19]. Vegetables may be infected by bacteria and parasites during the planting (through contaminated fertilizer, water source and soil), transportation, post-harvest or unhygienic cooking ([5,8,12]).

Using fresh stool as fertilizer is still popular in Vietnam. A previous survey implemented by Uga et al (2009) has shown that 81\% (121/149) farmers who lived in suburban Hanoi, Vietnam used animal and human feces as fertilizer frequently [23]. Therefore, the risk of microbiological infection related to vegetable consumption is still high whilst using raw vegetables in daily meals continues to play a key role in Vietnamese cuisine. The objective of this study was to evaluate the contamination of vegetables in traditional wet market in Hue city, Vietnam. Information obtained from this study will help vegetable consumers understand the current situation, and provide information to help local governments to develop policy to improve food safety and safeguard public health. 


\section{Materials and Methods}

\subsection{Sample Collection}

A total of 108 samples of twelve vegetables types were randomly collected from three traditional markets (Tay Loc, Ben Ngu and An Cuu) in Hue city, Vietnam between March 2013 and January 2014. For each vegetable type, three samples from three different stalls were collected. The twelve types of vegetables analyzed in this study were young mustard greens (Brassica juncea), celery (Apium graveolens), amaranth (Amaranthus tricolor), cilantro (Coriandrum sativum), water spinach (Ipomoea aquatica), rice paddy herb (Limnophila aromatica), Vietnamese cilantro (Persicaria odorata), basil (Ocimum basilicum), centella (Centella asiatica), lettuce (Lactuca sativa var. longifolia), watercress (Nasturtium officinale), and iceberg lettuce (Lactuca sativa var. capitata). Five hundred grams of each vegetable were collected, identified and placed in separate sterilized bags and immediately transported to the laboratory in an ice box.

\subsection{Evaluation of Aerobic Bacteria and $E$. coli Contamination}

Twenty five grams of chopped vegetable sample were aseptically transferred into a stomacher bag. Samples were homogenized for $2 \mathrm{~min}$ at high speed (260 rpm) with 225 $\mathrm{ml}$ of sterile peptone water $(0.1 \%$ peptone $)$ using a Stomacher ${ }^{\circledR} 400$ Circulator (Seward, UK) [6]. Serial decimal dilutions of the supernatant were made in sterile peptone water and aliquots of $0.1 \mathrm{ml}$ of the appropriate dilutions were surface spread in duplicate onto appropriate media. Total aerobic bacteria was enumerated on Plate Count Agar (PCA) (Oxoid CM 325, Unipath Ltd, Basingstoke, Hampshire, England) after incubation at $30^{\circ} \mathrm{C}$ for $48 \mathrm{~h}$ [6]. Escherichia coli contamination on vegetables was evaluated by counting all colonies exhibiting typical dark to purple red colonies with metallic sheen grown on Eosin methylene blue (EMB) agar (Conda Laboratories, S.A., Spain) after incubation at $37^{\circ} \mathrm{C}$ for $24 \mathrm{~h}$. Confirmation tests were made on $E$. coli colonies by Gram stain, catalase, oxydase and biochemical tests (API 20E strips, Biomerieux, USA) [22].

\subsection{Salmonella Detection}

Buffered Peptone Water $(10.0 \mathrm{~g} / \mathrm{l}$ peptone, $5.0 \mathrm{~g} / \mathrm{l}$ sodium chloride, 3.5g/l disodium phosphate, $1.5 \mathrm{~g} / \mathrm{l}$ monopotassium phosphate, $\mathrm{pH}$ 7.2) was used for preenrichment [1] Twenty five grams of chopped vegetable sample were aseptically transferred into a stomacher bag containing $225 \mathrm{ml}$ of Buffered Peptone Water, followed by homogenized for $2 \mathrm{~min}$ at high speed (260 rpm) using a Stomacher ${ }^{\circledR} 400$ Circulator (Seward, UK) [14]. The homogenized samples were incubated at $37^{\circ} \mathrm{C}$ for $24 \mathrm{~h}$.

Bacterial chromosomal DNA was isolated using DNA boiling method. Bacteria suspension was centrifuged at $8,000 \mathrm{rpm}$ for $8 \mathrm{~min}$. The supernatant was removed and the pellet was resuspended in PBS $(8 \mathrm{~g} / \mathrm{l} \mathrm{NaCl}, 0.2 \mathrm{~g} / \mathrm{l} \mathrm{KCl}$; 1.44g/l $\quad \mathrm{Na}_{2} \mathrm{HPO}_{4}, 0.24 \mathrm{~g} / \mathrm{l} \quad \mathrm{KH}_{2} \mathrm{PO}_{4}, \quad \mathrm{pH}$ 7.2). The suspension was boiled in water bath at $100^{\circ} \mathrm{C}$ for $10 \mathrm{~min}$ and transferred into ice box immediately. After cooling down, it was centrifuged at 3,000 rpm for $10 \mathrm{~min}$. The supernatant was collected for PCR [2]. DNA of Salmonella enterica subsp. diarizonae $\left(\right.$ ATCC $^{\circledR} 12325^{\mathrm{TM}}$ ) was used as positive control.

The invA gene of Salmonella was amplified using PCR technique with primer set 139: 5'GTG AAA TTA TCG CCA CGT TCG GGC AA-3' and 141: 5'TCA TCG CAC CGT CAA AGG AAC C-3' [17]. PCR product size was 284bp. The PCR mixture contained $12.5 \mu \mathrm{l}$ of GoTaq $^{\circledR}$ Green Master Mix, $1.0 \mathrm{pmol}$ of each primer, $4.0 \mu \mathrm{l}$ of DNA template and nuclease-free water for a final volume of $25 \mu$ l. Amplification was performed using a gradient thermal cycler (MaxyGene, Axygen). The cycling conditions were as follows: heat denaturation at $94^{\circ} \mathrm{C}$ for $5 \mathrm{~min}$, and then 35 cycles with heat denaturation at $94^{\circ} \mathrm{C}$ for $1 \mathrm{~min}$, primer annealing at $64^{\circ} \mathrm{C}$ for $1 \mathrm{~min}$, DNA elongation at $72^{\circ} \mathrm{C}$ for $1 \mathrm{~min}$ and final extension for $7 \mathrm{~min}$ at $72^{\circ} \mathrm{C}$. Amplified products were electrophoresed in $2 \%$ agarose gel, stained with ethidium bromide $(0.5 \mu \mathrm{l} / \mathrm{ml})$, visualized and photographed with Gel Doc ${ }^{\mathrm{TM}} \mathrm{XR}+$ system (Biorad).

\subsection{Parasitic Contamination Detection}

A 10 gram chopped vegetable sample was transferred into a stomacher bag containing $100 \mathrm{ml}$ of sterile distilled water and homogenized for $2 \mathrm{~min}$ at $260 \mathrm{rpm}$ using a Stomacher ${ }^{\circledR} 400$ Circulator (Seward, UK). Homogenized samples were centrifuged at $1200 \times \mathrm{g}$ for $10 \mathrm{~min}$. The supernatant was discarded and $2 \mathrm{ml}$ of the pellet was collected [24]. The next steps were done following the modified Bailenger method [3]. The pellet was suspended in an equal volume of acetoacetic buffer (1 liter of buffer contained $15 \mathrm{~g}$ sodium acetate trihydrate and $3.6 \mathrm{ml}$ glacial acetic acid, $\mathrm{pH} 4.5$ ) and two volumes of ethyl acetate or ether. The mixture was mixed throughly in a vortex mixer and centrifuged at $1000 \times \mathrm{g}$ in $15 \mathrm{~min}$. After centrifugation, the sample was separated into three phases. The bottom phase contained heavy debris, including helminth eggs, larvae and protozoa. The middle layer was buffer. The materials dissolved into ethyl ether or ether formed were in the top layer. The supernatant was discarded and 5 volumes of $33 \%$ zinc sulfate solution was used to resuspend the pellet. After, thorough mixing the sample was then tested for the presence of parasites.

Helminth eggs were detected in the sample under a light microscope using $\times 40$ magnification and identified according to the description of Ayres and Mara (1996) [3]. Protozoa were detected by staining the specimens following modified Ziehl-Neelsen technique [4]. The sample was smeared directly onto a microscope slide and air dried. The slide was then prefixed in absolute methanol for 5-10 sec, stained in carbol fuchsine - DMSO (4g of basic fuchsin crystals, $25 \mathrm{ml}$ of $99 \%$ ethyl alcohol, $12 \mathrm{~g}$ of phenol crystals, $25 \mathrm{ml}$ of glycerol, $25 \mathrm{ml}$ of dimethyl sulfoxide and $75 \mathrm{ml}$ of distilled water) for $5 \mathrm{~min}$. The slide was rinsed under running tap water for 10-30 sec until excess solution no longer ran off. The slide was placed in decolorizer-counter-stain solution $(220 \mathrm{ml}$ of $2 \%$ aqueous solution of malachite green, $30 \mathrm{ml}$ of glacial acid acetic and $50 \mathrm{ml}$ of glycerol) for $1 \mathrm{~min}$ or until a green background appeared. The slide was then rinsed under running tap water for $10 \mathrm{sec}$, drained and air dried. Observing the slide under a light microscope using $\times 100$ 
magnification and identifying the parasites according to the description of Ribes et al (1996) [18].

\subsection{Statistical data Analysis}

The data were analyzed using general linear model (GLM) in SPSS software version 18.0. Results presented in tables are mean \pm standard deviation. Significant differences among means were separated by Tukey test with a $5 \%$ level of probability.

\section{Results and Discussion}

\subsection{Bacterial Contamination on Vegetables}

The study results showed that all vegetable samples were contaminated with aerobic bacteria and E. coli. The average concentrations of aerobic bacteria and $E$. coli ranged from 6.84 to $8.40 \mathrm{log}$ CFU/g and 5.47 - $6.88 \mathrm{log}$ CFU/g, respectively (Table 1 ). The $E$. coli concentrations detected were higher than the acceptable limit $\left(10^{2}-10^{3}\right.$
CFU/g) for fresh vegetables according to Vietnamese technical regulation of microbiological contaminants in food QCVN 8-3: 2012/BYT. There was a significant difference in $E$. coli load detected in the same type of vegetable between the three markets, especially in celery, cilantro and Vietnamese cilantro (Table 1). Meanwhile, the highest variation of total aerobic bacteria concentration was detected on water spinach (7.52 - 9.45 $\log \mathrm{CFU} / \mathrm{g})$, followed by Vietnamese cilantro (6.82 - 7.81 $\log \mathrm{CFU} / \mathrm{g})$.

This result was higher than that in other previous reports $[11,19]$. The total aerobic bacteria found on leafy vegetables from small shops in Granada (Spain) was $10^{4}$ $10^{6} \mathrm{CFU} / \mathrm{g}$ or $4-6 \log \mathrm{CFU} / \mathrm{g}$ [19]. In the same study, the authors also indicated a high degree of fecal contamination with $86.1 \%$ vegetable samples examined contaminated with E. coli [19]. Meanwhile, the concentrations of aerobic bacteria (4.5 - $6.2 \mathrm{log}$ CFU/g) and $E$. coli $(0.7$ - $1.0 \log \mathrm{CFU} / \mathrm{g})$ were found on leafy vegetables and herbs from the southern United States [11].

Table 1. Aerobic bacteria and $E$. coli concentrations on the examined vegetables

\begin{tabular}{|c|c|c|c|c|c|c|c|c|}
\hline \multirow{2}{*}{ Vegetables } & \multicolumn{4}{|c|}{ Aerobic bacteria (log CFU/g) } & \multicolumn{4}{|c|}{ E. coli $(\log \mathrm{CFU} / \mathrm{g})$} \\
\hline & $\begin{array}{c}\text { An Cuu } \\
\text { market }\end{array}$ & $\begin{array}{c}\text { Ben Ngu } \\
\text { market }\end{array}$ & $\begin{array}{c}\text { Tay Loc } \\
\text { market }\end{array}$ & Average & $\begin{array}{c}\text { An Cuu } \\
\text { market }\end{array}$ & $\begin{array}{c}\text { Ben Ngu } \\
\text { market }\end{array}$ & $\begin{array}{c}\text { Tay Loc } \\
\text { market }\end{array}$ & Average \\
\hline $\begin{array}{c}\text { Young mustard } \\
\text { greens }\end{array}$ & $\begin{array}{c}7.81 \\
\pm 0.17 \\
\end{array}$ & $\begin{array}{c}7.70 \\
\pm 0.59\end{array}$ & $\begin{array}{c}7.67 \\
\pm 0.06 \\
\end{array}$ & $\begin{array}{l}7.73^{\mathrm{abc}} \\
\pm 0.31\end{array}$ & $\begin{array}{c}7.67 \\
\pm 0.77 \\
\end{array}$ & $\begin{array}{c}6.73 \\
\pm 0.16 \\
\end{array}$ & $\begin{array}{c}6.05 \\
\pm 0.16\end{array}$ & $\begin{array}{c}6.81^{\mathrm{a}} \\
\pm 0.81 \\
\end{array}$ \\
\hline Celery & $\begin{array}{c}8.59 \\
\pm 0.54 \\
\end{array}$ & $\begin{array}{c}8.57 \\
\pm 0.36 \\
\end{array}$ & $\begin{array}{c}7.70 \\
\pm 0.54 \\
\end{array}$ & $\begin{array}{l}8.29^{\mathrm{ab}} \\
\pm 0.61\end{array}$ & $\begin{array}{c}8.55 \\
\pm 0.69 \\
\end{array}$ & $\begin{array}{c}6.21 \\
\pm 0.41 \\
\end{array}$ & $\begin{array}{c}5.89 \\
\pm 0.02 \\
\end{array}$ & $\begin{array}{c}6.88^{\mathrm{a}} \\
\pm 1.32 \\
\end{array}$ \\
\hline Amaranth & $\begin{array}{c}8.24 \\
\pm 0.48 \\
\end{array}$ & $\begin{array}{c}8.14 \\
\pm 0.19 \\
\end{array}$ & $\begin{array}{c}8.28 \\
\pm 0.08 \\
\end{array}$ & $\begin{array}{l}8.22^{\mathrm{ab}} \\
\pm 0.27\end{array}$ & $\begin{array}{c}6.80 \\
\pm 0.07 \\
\end{array}$ & $\begin{array}{c}6.34 \\
\pm 0.24 \\
\end{array}$ & $\begin{array}{c}5.92 \\
\pm 0.39\end{array}$ & $\begin{array}{l}6.35^{\mathrm{ab}} \\
\pm 0.45\end{array}$ \\
\hline Water spinach & $\begin{array}{c}8.24 \\
\pm 0.24 \\
\end{array}$ & $\begin{array}{c}7.52 \\
\pm 0.12 \\
\end{array}$ & $\begin{array}{c}9.45 \\
\pm 0.10 \\
\end{array}$ & $\begin{array}{r}8.40^{\mathrm{a}} \\
\pm 0.85 \\
\end{array}$ & $\begin{array}{c}7.07 \\
\pm 0.42 \\
\end{array}$ & $\begin{array}{c}6.06 \\
\pm 0.18 \\
\end{array}$ & $\begin{array}{c}5.73 \\
\pm 0.22 \\
\end{array}$ & $\begin{array}{l}6.28^{\mathrm{ab}} \\
\pm 0.66 \\
\end{array}$ \\
\hline Cilantro & $\begin{array}{c}7.73 \\
\pm 0.14 \\
\end{array}$ & $\begin{array}{c}8.51 \\
\pm 0.33 \\
\end{array}$ & $\begin{array}{r}7.94 \\
\pm 0.23 \\
\end{array}$ & $\begin{array}{l}8.06^{\mathrm{ab}} \\
\pm 0.41 \\
\end{array}$ & $\begin{array}{c}8.23 \\
\pm 0.61 \\
\end{array}$ & $\begin{array}{r}5.98 \\
\pm 0.65 \\
\end{array}$ & $\begin{array}{c}5.93 \\
\pm 0.46 \\
\end{array}$ & $\begin{array}{c}6.71^{\mathrm{a}} \\
\pm 1.24 \\
\end{array}$ \\
\hline Rice paddy herb & $\begin{array}{c}7.91 \\
\pm 0.66 \\
\end{array}$ & $\begin{array}{r}7.86 \\
\pm 0.47 \\
\end{array}$ & $\begin{array}{c}7.06 \\
\pm 0.71 \\
\end{array}$ & $\begin{array}{c}7.61^{\text {abcd }} \pm \\
0.68\end{array}$ & $\begin{array}{c}7.50 \\
\pm 0.53 \\
\end{array}$ & $\begin{array}{c}6.05 \\
\pm 0.73 \\
\end{array}$ & $\begin{array}{c}5.74 \\
\pm 0.45\end{array}$ & $\begin{array}{l}6.43^{\mathrm{ab}} \\
\pm 0.96\end{array}$ \\
\hline Vietnamese cilantro & $\begin{array}{c}6.82 \\
\pm 0.30 \\
\end{array}$ & $\begin{array}{c}7.72 \\
\pm 0.08 \\
\end{array}$ & $\begin{array}{c}7.81 \\
\pm 0.81 \\
\end{array}$ & $\begin{array}{l}7.45^{\text {bcd }} \\
\pm 0.64\end{array}$ & $\begin{array}{c}7.92 \\
\pm 1.24 \\
\end{array}$ & $\begin{array}{c}6.67 \\
\pm 0.29 \\
\end{array}$ & $\begin{array}{c}5.74 \\
\pm 0.07 \\
\end{array}$ & $\begin{array}{c}6.78^{\mathrm{a}} \\
\pm 1.14 \\
\end{array}$ \\
\hline Basil & $\begin{array}{c}7.66 \\
\pm 0.58 \\
\end{array}$ & $\begin{array}{c}7.07 \\
\pm 0.04 \\
\end{array}$ & $\begin{array}{c}6.81 \\
\pm 0.14 \\
\end{array}$ & $\begin{array}{l}7.18^{\mathrm{cd}} \\
\pm 0.48\end{array}$ & $\begin{array}{c}6.21 \\
\pm 0.66\end{array}$ & $\begin{array}{c}6.43 \\
\pm 0.22\end{array}$ & $\begin{array}{c}6.09 \\
\pm 0.23\end{array}$ & $\begin{array}{l}6.24^{\mathrm{ab}} \\
\pm 0.39\end{array}$ \\
\hline Centella & $\begin{array}{c}6.55 \\
\pm 0.23\end{array}$ & $\begin{array}{c}7.63 \\
\pm 0.49\end{array}$ & $\begin{array}{c}6.67 \\
\pm 0.37\end{array}$ & $\begin{array}{l}6.95^{\mathrm{cd}} \\
\pm 0.61\end{array}$ & $\begin{array}{c}6.15 \\
\pm 0.21\end{array}$ & $\begin{array}{c}7.13 \\
\pm 1.02 \\
\end{array}$ & $\begin{array}{c}5.84 \\
\pm 0.80\end{array}$ & $\begin{array}{l}6.37^{\mathrm{ab}} \\
\pm 0.88\end{array}$ \\
\hline Lettuce & $\begin{array}{c}7.32 \\
\pm 0.10 \\
\end{array}$ & $\begin{array}{c}6.57 \\
\pm 0.25 \\
\end{array}$ & $\begin{array}{c}7.09 \\
\pm 0.41 \\
\end{array}$ & $\begin{array}{l}6.99^{\text {cd }} \\
\pm 0.41 \\
\end{array}$ & $\begin{array}{c}5.36 \\
\pm 0.24 \\
\end{array}$ & $\begin{array}{c}5.32 \\
\pm 0.70 \\
\end{array}$ & $\begin{array}{c}6.80 \\
\pm 0.55 \\
\end{array}$ & $\begin{array}{l}5.82^{\mathrm{ab}} \\
\pm 0.86 \\
\end{array}$ \\
\hline Watercress & $\begin{array}{c}6.84 \\
\pm 0.45 \\
\end{array}$ & $\begin{array}{c}6.98 \\
\pm 0.12 \\
\end{array}$ & $\begin{array}{c}6.70 \\
\pm 0.25 \\
\end{array}$ & $\begin{array}{c}6.84^{\mathrm{d}} \\
\pm 0.29 \\
\end{array}$ & $\begin{array}{c}5.45 \\
\pm 0.41 \\
\end{array}$ & $\begin{array}{c}6.15 \\
\pm 0.25 \\
\end{array}$ & $\begin{array}{c}4.80 \\
\pm 0.42 \\
\end{array}$ & $\begin{array}{c}5.48^{\mathrm{b}} \\
\pm 0.54 \\
\end{array}$ \\
\hline Iceberg lettuce & $\begin{array}{c}7.21 \\
\pm 0.43\end{array}$ & $\begin{array}{c}7.18 \\
\pm 0.19\end{array}$ & $\begin{array}{c}6.49 \\
\pm 0.31\end{array}$ & $\begin{array}{l}6.96^{\mathrm{cd}} \\
\pm 0.45\end{array}$ & $\begin{array}{c}5.63 \\
\pm 0.48\end{array}$ & $\begin{array}{c}5.80 \\
\pm 0.45\end{array}$ & $\begin{array}{c}5.05 \\
\pm 0.47\end{array}$ & $\begin{array}{c}5.47^{\mathrm{b}} \\
\pm 0.66 \\
\end{array}$ \\
\hline
\end{tabular}

${ }^{\mathrm{a}-\mathrm{c}}$ Means with different superscripts within a column differ significantly ( $\mathrm{p}<0.05$ ).

Table 2. Aerobic bacteria and $E$. coli contamination on the vegetables between markets

\begin{tabular}{|c|c|c|c|}
\hline Market & $\begin{array}{c}\text { Number of } \\
\text { samples }\end{array}$ & $\begin{array}{c}\text { Aerobic } \\
\text { bacteria } \\
\text { (log CFU/g) }\end{array}$ & $\begin{array}{c}\text { E. coli } \\
\text { (log CFU/g) }\end{array}$ \\
\hline An Cuu & 36 & $7.58^{\mathrm{a}} \pm 0.70$ & $6.88^{\mathrm{a}} \pm 1.19$ \\
\hline Ben Ngu & 36 & $7.62^{\mathrm{a}} \pm 0.65$ & $6.24^{\mathrm{b}} \pm 0.62$ \\
\hline Tay Loc & 36 & $7.47^{\mathrm{a}} \pm 0.89$ & $5.79^{\mathrm{c}} \pm 0.60$ \\
\hline Total & 108 & $7.56 \pm 0.75$ & $6.30 \pm 0.95$ \\
\hline
\end{tabular}

${ }^{\mathrm{a}-\mathrm{c}}$ Means with different superscripts within a column differ significantly $(\mathrm{p}<0.05)$.

There was no significant difference in total aerobic bacteria count on vegetable samples between the three markets (Table 2, p > 0.05). However, the concentrations of $E$. coli detected on the samples differed significantly between Tay Loc, An Cuu and Ben Ngu markets. The lowest degree of $E$. coli contamination on vegetables was found at Tay Loc market (5.79 log CFU/g). Conversely, the highest contamination with $E$. coli was detected on vegetables collected from An Cuu market (6.88 log $\mathrm{CFU} / \mathrm{g})$.

Being able to get results quickly is one of the advantages of using PCR technique on Salmonella detection, compared to traditional culture method. Moreover, the dead Salmonella cells are can be detected using PCR. Amplification of invA gene sequence of Salmonella has been being used for detecting Salmonella in poultry, meats and dairy products, and in vegetables and fruits [9]. The result of invA gene amplification is presented in Figure 1. 


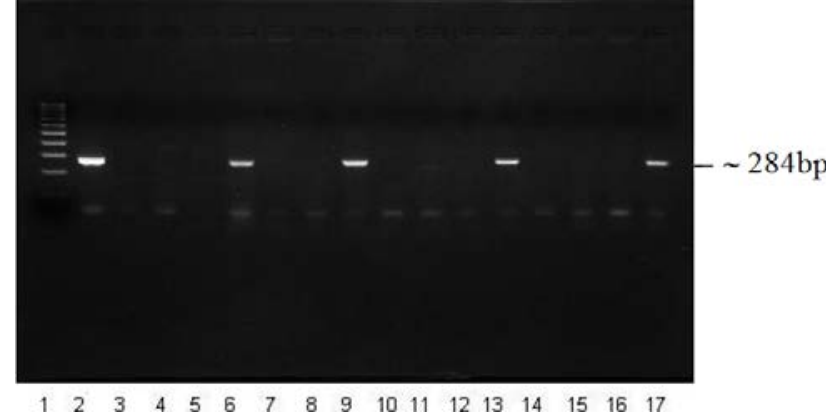

Figure 1. Detection of Salmonella by PCR from the examined vegetables

Lane 1: 100bp DNA ladder, lane 2: postivive control - Salmonella enterica subsp. diarizonae (ATCC ${ }^{\circledR} 12325^{\mathrm{TM}}$ ), lane 3: negative control nulease-free water, lane 4: E. coli, lanes 5 to 17: examined vegetables
Eighteen percent (19/108) of samples were contaminated with Salmonella (Table 3). The percentage of Salmonella-positive samples from each market were Tay Loc 7/36 (19.44\%), Ben Ngu 5/36 (13.89\%) and An Cuu 7/36 (19.44\%). Most vegetable types were contaminated with Salmonella except cilantro, Vietnamese cilantro, basil and centella. The highest prevalence of Salmonella contamination was found on water spinach (55.56\%). A previous study carried out by Ruiz et al (1987) has shown that Salmonella was detected in $7.5 \%$ of the examined vegetables in Granada (Spain). Furthermore, the study result of Quiroz-Santiago et al (2009) showed that 98/1700 vegetable samples collected in Mexico was contamniated with Salmonella [16]. The prevalence of Salmonella contamination in each type of vegetables ranged from $1 \%$ to $12 \%$ [16].

Table 3. Prevalence of Salmonella contamination on the examined vegetables

\begin{tabular}{|c|c|c|c|c|c|}
\hline \multirow[b]{2}{*}{ Vegetables } & \multirow[b]{2}{*}{ Number of samples } & \multicolumn{3}{|c|}{ Salmonella positive samples } & \multirow{2}{*}{$\begin{array}{c}\text { Prevalence of } \\
\text { Salmonella } \\
\text { contamination (\%) }\end{array}$} \\
\hline & & $\begin{array}{l}\text { Tay Loc market } \\
\qquad(\mathrm{n}=3)\end{array}$ & $\begin{array}{c}\text { Ben Ngu market } \\
(\mathrm{n}=3)\end{array}$ & $\begin{array}{c}\text { An Cuu market } \\
(\mathrm{n}=3)\end{array}$ & \\
\hline Young mustard greens & 9 & 1 & 1 & 0 & 22.22 \\
\hline Celery & 9 & 1 & 0 & 2 & 33.33 \\
\hline Amaranth & 9 & 0 & 1 & 0 & 11.11 \\
\hline Cilantro & 9 & 0 & 0 & 0 & 0.00 \\
\hline Water spinach & 9 & 1 & 2 & 2 & 55.56 \\
\hline Rice paddy herb & 9 & 0 & 0 & 1 & 11.11 \\
\hline Vietnamese cilantro & 9 & 0 & 0 & 0 & 0.00 \\
\hline Basil & 9 & 0 & 0 & 0 & 0.00 \\
\hline Centella & 9 & 0 & 0 & 0 & 0.00 \\
\hline Lettuce & 9 & 3 & 0 & 0 & 33.33 \\
\hline Watercress & 9 & 1 & 0 & 2 & 33.33 \\
\hline Iceberg lettuce & 9 & 0 & 1 & 0 & 11.11 \\
\hline Total & 108 & 7 & 5 & 7 & 17.59 \\
\hline
\end{tabular}

Bacteria can contaminate vegetables in different ways and at different points in time. The study result of Enabulele and Uraih (2009) indicated that the source of $E$. coli contamination on vegetables sold in Benin (Nigeria) was contaminated irrigated water [5]. This contaminated water had come from contact with grazing cattle and cross contamination from the vehicles that were used for animal transportation prior to carrying vegetables. In addition to this, Salmonella-contaminated wastewater used for irrigation in Marrakesh city (Morocco) caused contamination on vegetables was also reported [13]; and a study on the microbiological quality of carrots used for fresh juice preparation in India showed that there was a large increase in total aerobic bacteria and Staphylococcus on carrots as they travelled further through the distribution chain [8]. The total aerobic bacteria and Staphylococcus counts detected on carrots increased from $10^{4}$ to $3.6 \times 10^{7}$ CFU/g and from $1.9 \times 10^{4}$ to $7.7 \times 10^{6} \mathrm{CFU} / \mathrm{g}$, respectively during the transportation from the central distribution site to street vendors. It is posited that unhygienic handling, cross contamination and water quality caused the contamination of the carrots [8].

\subsection{Parasitic Contamination on Vegetables}

All vegetable samples were contaminated with parasites. The parasites most commonly detected were Fasciola (eggs, 83.33\%), Ascaris (eggs, 85.19\%) and Trichuris (eggs, 64.81\%) (Table 4). Clonorchis sinensis eggs was also detected with the frequency of $16.67 \%$. In addition, oocysts of some protozoa as Cryptosporidium, Isospora and Cyclospora were found on the test samples. The Cryptosporidium contamination ratio on 12 types of examined vegetables ranged from $22.22 \%$ to $66.67 \%$. The number of samples contaminated with Isospora and Cyclospora were relatively low. Cilantro was Cyclosporafree. Of twelve types of examined vegetables, watercress was the vegetable most infected by parasites, followed by basil and lettuce.

The parasitic contamination on vegetables in Vietnam was also reported [23]. There were $26 \%$ vegetable samples collected from a suburban market in Hanoi (Vietnam) contaminated with helminth eggs. Leafy vegetables had the highest contamination ratio (31\%; [23]). The five main types of parasite eggs were found in that study were Ascaris sp., Trichuris sp., Toxocara sp., Taenia sp. and Ascaridia galli [23]. Furthermore, Kłapeć and Borecka (2012) also reported the contamination of vegetables, fruits and soil on organic and conventional farms with parasite eggs (Ascaris, Trichuris and Toxocara) in south-eastern Poland [12]. The situation of contamination with parasites on vegetables in other countries was also reported, for example in Iran [7], Nigeria [10], Semnan [15], Egypt [20] and Philippines [21]. The reasons of parasitic contamination on vegetables were probably contaminated from fertilizer ([23], [12]), wastewater source [24], soil [12]. 
Table 4. Prevalence of parasitic contamination on vegetables

\begin{tabular}{|c|c|c|c|c|c|c|c|c|}
\hline \multirow{2}{*}{ Vegetables } & \multirow{2}{*}{$\begin{array}{l}\text { Number } \\
\text { of samples }\end{array}$} & \multicolumn{7}{|c|}{ Positive ratio (\%) } \\
\hline & & $\begin{array}{c}\text { Fasciola } \\
\text { egg }\end{array}$ & $\begin{array}{c}\text { Ascaris } \\
\text { egg }\end{array}$ & $\begin{array}{c}\text { Trichuris } \\
\text { egg }\end{array}$ & $\begin{array}{c}\text { Clonorchis } \\
\text { sinensis egg }\end{array}$ & $\begin{array}{c}\text { Cryptos- } \\
\text { poridium oocyst }\end{array}$ & $\begin{array}{c}\text { Cyclospora } \\
\text { oocyst }\end{array}$ & $\begin{array}{c}\text { Isospora } \\
\text { oocyst }\end{array}$ \\
\hline $\begin{array}{l}\text { Young mustard } \\
\text { greens }\end{array}$ & 9 & 100.00 & 77.78 & 77.78 & 0.00 & 44.44 & 22.22 & 33.33 \\
\hline Celery & 9 & 88.89 & 77.78 & 77.78 & 0.00 & 33.33 & 33.33 & 33.33 \\
\hline Amaranth & 9 & 88.89 & 77.78 & 55.56 & 0.00 & 22.22 & 33.33 & 22.22 \\
\hline Water spinach & 9 & 100.00 & 88.89 & 66.67 & 0.00 & 55.56 & 33.33 & 11.11 \\
\hline Cilantro & 9 & 100.00 & 88.89 & 66.67 & 0.00 & 33.33 & 0.00 & 22.22 \\
\hline Rice paddy herb & 9 & 100.00 & 77.78 & 66.67 & 0.00 & 55.56 & 11.11 & 33.33 \\
\hline Vietnamese cilantro & 9 & 100.00 & 100.00 & 66.67 & 0.00 & 44.44 & 22.22 & 11.11 \\
\hline Basil & 9 & 77.78 & 77.78 & 66.67 & 44.44 & 55.56 & 33.33 & 22.22 \\
\hline Centella & 9 & 55.56 & 88.89 & 44.44 & 33.33 & 66.67 & 22.22 & 22.22 \\
\hline Lettuce & 9 & 77.78 & 88.89 & 66.67 & 33.33 & 55.56 & 22.22 & 33.33 \\
\hline Watercress & 9 & 44.44 & 100.00 & 77.78 & 66.67 & 44.44 & 55.56 & 33.33 \\
\hline Iceberg lettuce & 9 & 66.67 & 77.78 & 44.44 & 22.22 & 55.56 & 44.44 & 55.56 \\
\hline Total & 108 & 83.33 & 85.19 & 64.81 & 16.67 & 47.22 & 27.78 & 27.78 \\
\hline
\end{tabular}

Alam, Md.Z., "Performance analysis of multiplex in chicken egg samples", Singapore Journal of Scientific Research, 2, 25-32,

\section{Conclusion}

Contamination with bacteria and parasites was detected on a range of vegetables at the three big, traditional markets in Hue city. All of examined vegetables samples were contaminated with multiple bacteria and parasites. Contamination levels of E. coli and Salmonella on most of vegetables examined were higher than acceptable limits for fresh vegetables according to Vietnamese technical regulations on microbiological contamination in food. Vegetables contaminated in this way can become potential sources of cross contamination and pose a serious risk to human health. Therefore, with the aim of reducing the risk of cross contamination and food poisoning, washing vegetables after harvest and before using is very important. Studies aimed at reducing pathogen contamination in the field, during transportation, and to limit or remove pathogens on vegetables after harvest are necessary to supply safe vegetables to consumers.

\section{Acknowledgement}

We would like to acknowledge the financial support of the Graduate School of Global Environmental Studies, Kyoto University, Japan. We also thank Dr. Mary Kathryn Finlay-Doney for her support in English writing.

\section{Statement of Competing Interests}

The authors have no competing interests.

\section{References}

[1] Adjrah, Y., Karou, D.S., Djéri, B., Anani, K., Soncy, K., Ameyapoh, Y., de Souza, C., Gbeassor, M., "Hygienic quality of commonly consumed vegetables. and perception about disinfecting agents in Lomé", International Food Research Journal, 18(4), 1499-1503, 2011.

[2] Ahmed, M.M., Hossain, Md.S., Mahbub, K.R., Khaleque, H.N., Hossain, Z., Fakruddin, Md., Chowdhury, A., Hossain, Md.N.,
[3] Ayres, R.M., Mara, D.D., Analysis of wastewater for use in agriculture - A laboratory manual of parasitological and bacteriological techniques, World Health Organization, Geneva, Switzerland, 1996.

[4] Bronsdon, M.A., "Rapid dimethyl sulfoxide-modified acid-fast stain of Cryptosporidium oocysts in stool specimens", Journal of Clinical Microbiology, 19(6), 952-953, 1984.

[5] Enabulele S.A., Uraih N. (2009), Enterohaemorrhagic Escherichia coli 0157:H7 prevalence in meat and vegetables sold in Benin City, Nigeria, African Journal of Microbiology Research, 3 (5), pp. 276279.

[6] Francis, G.A., O’Beirne, D., "Effects of vegetable type and antimicrobial dipping on survival and growth of Listeria innocua and E. coli", International Journal of Food Science and Technology, 37, 711-718, 2002.

[7] Gharavi, M.J., Jahani, M.R., Rokni, M.B., "Parasitic contamination of vegetables from farms and markets in Tehran", Iranian Journal of Public Health, 31, 83-86, 2002.

[8] Ghosh, M., Ganguli, A., Mudgil, S., "Microbiological quality of carrots used for preparation of fresh squeezed street vended carrot juices in India", Journal of Food Agriculture and Environment, 2(2), 143-145, 2004.

[9] Guo, X., Chen, J., Beuchat, L.R., Brackett, R.E., "PCR detection of Salmonella enterica serotype Montevideo in and on raw tomatoes using primers derived from hilA", Applied and Environmental Microbiology, 66, 5248-5252, 2000.

[10] Idahosa, O.T., "Parasitic contamination of fresh vegetables sold in Jos markets", Global Journal of Medical Research, 11(1), 20-25, 2011.

[11] Johnston, L.M., Jaykus, L., Moll, D., Martinez, M.C., Anciso, J., Mora, B., Moe, C.L., "A field study of the microbiological quality of fresh produce", Journal of Food Protection, 68(9), 1840-1847, 2005.

[12] Kłapeć, T., Borecka, A., "Contamination of vegetables. fruits and soil with geohelminths eggs con organic farm in Poland", Annals of Agricultural and Environmental Medicine, 19 (3), 421-425, 2012.

[13] Melloul, A.A., Hassani, L., Rafouk, L., "Salmonella contamination of vegetables irrigated with untreated wastewater", World Journal of Microbiology and Biotechnology, 17, 207-209, 2001.

[14] Mukherjee, A., Speh, D., Dyck, E., Diez-Gonzalez, F., "Preharvest evaluation of coliforms, Escherichia coli O157:H7 in organic and conventional produce grown by Minnesota farmers", Journal of Food Protection, 67(5), 894-900, 2004.

[15] Nazemi, A., Raei, M., Amiri, M., Chaman, R., "Parasitic contamination of raw vegetables in Shahroud, Semnan, Zahedan", Journal of Research in Medical Sciences, 14(8), 84-86, 2012.

[16] Quiroz-Santiago, C., Rodas-Suárez, O.R., Carlos R.V., Fernández, F.J., Quiñones-Ramírez, El., Vázquez-Salinas, C., "Prevalence of 
Salmonella in vegetables from Mexico", Journal of Food Protection, 72 (6), pp. 1279-1282, 2009.

[17] Rahn, K., De Grandis, S.A., Clarke, R.C., McEwen, S.A., Galán, J.E., Ginocchio, C., Curtiss, R.III., Gyles, C.L., "Amplification of an invA gene sequence of Salmonella typhimurium by polymerase chain reaction as a specific method of detection of Salmonella", Molecular and Cellular Probes, 6(4), 271-279, 1992.

[18] Ribes, J.A., Seabolt, J.P., Overman, S.B., "Point prevalence of Cryptosporidium, Cyclospora and Isospora infections in patients being evaluated for diarrhea", American Journal of Clinical Pathology, 122, 28-32, 2004.

[19] Ruiz, B.G., Vargas, R.G., Garcia-Villanova, R., "Contamination on fresh vegetables during cultivation and marketing", International Journal of Food Microbiology, 4(4), 285-291, 1987.

[20] Said Said, D.E., "Detection of parasites in commonly consumed raw vegetables", Alexandria Journal of Medicine, 48, 345-352, 2012.
[21] Sia Su, G.L., Mariano, C.M.R., Matti, N.S.A., Ramos, G.B., "Assessing parasitic infestation of vegetables in selected market in Metro Manila, Philippines", Asian Pacific Journal of Tropical Disease, 51-54, 2012.

[22] Thenmozhi, M., "Isolation of potentially pathogenic Escherichia coli O157:H7 from the water sources", International Journal of Pharma and Bio Sciences, 1(4), B84-B88, 2010.

[23] Uga, S., Hoa, N.T.V., Noda, S., Moji, K., Cong, L., Aoki, Y., Rai, S.K., Fujimaki, Y., "Parasite egg contamination of vegetables from a suburban market in Hanoi, Vietnam", Nepal Medical College Journal, 11(2), 75-78, 2009.

[24] Vuong, T.A., Nguyen, T.T., Klank, L.T., Phung, D.C., Dalsgaard, A., "Faecal and protozoan parasite contamination of water spinach (Ipomoea aquatica) cultivated in urban wastewater in Phnom Penh, Cambodia", Tropical Medicine \& International Health, 12(Suppl 2), 73-81, 2007 